\title{
Saprolmycins A-E, new angucycline antibiotics active against Saprolegnia parasitica
}

\author{
Kazuya Nakagawa ${ }^{1}$, Choko Hara $^{2}$, Shinji Tokuyama ${ }^{2}$, Kentaro Takada ${ }^{3,4}$ and Nobutaka Imamura ${ }^{3}$ \\ Saprolmycins A-E, five new anti-Saprolegnia parasitica antibiotics were isolated from the culture broth of Streptomyces sp. \\ strain TK08046. As determined using a combination of NMR and spectroscopic analyses, the structures of these compounds \\ were elucidated as a new group of angucycline compounds closely related to saquayamycin. Saprolmycin A and E exhibited \\ potent anti-S. parasitica selective activities, with MIC values of 3.9 and $7.8 \mathrm{ng} \mathrm{ml}^{-1}$, respectively, but weak or no activity \\ against fungi, gram-positive or -negative bacteria, and microalgae or zooplankton. Our results suggest these two compounds \\ as highly effective and environmentally safe anti-saprolegniasis candidates.
}

The Journal of Antibiotics (2012) 65, 599-607; doi:10.1038/ja.2012.86; published online 24 October 2012

Keywords: angucycline; saprolegniasis; Saprolegnia parasitica; streptomycetes

\section{INTRODUCTION}

Oomycetes represent a diverse group of plant and animal pathogens; Phytophthora infestans is one of the most important potato and tomato pathogens, Pythium insidiosm is an oomycete that can cause serious life-threatening infections in humans and animals, and the water-mold family Saprolegniaceae including Saprolegnia parasitica are fish and crayfish pathogens in ecosystems and can cause enormous damage to fish farms. ${ }^{1}$ The lifecycle of Saprolegniaceae includes stages similar to those of the true fungi, such as hyphal elongation, spore formation and germination. ${ }^{2}$ Important distinction of Saprolegniaceae includes the presence of cellulose and chitin in their cell walls (true fungi contain only chitin) and their relatedness to brown algae, as determined by $18 \mathrm{~S}$ rDNA analysis. ${ }^{3-5}$ In the aquaculture industry, saprolegniasis has been controlled effectively with malachite green, although recent studies have shown this compound to be environmentally toxic. ${ }^{6-12}$ Research conducted over the past two decades has reported mutagenic, teratogenic and residual unfavorable activities of malachite green leading to its ban in many countries. ${ }^{7-12} \mathrm{~A}$ broad-spectrum bactericide substance known as bronopol has been used for preventing saprolegniasis outbreak in salmon and trout eggs populations. However, due to its broad bioactivity $^{13}$ and demonstrated toxicities against environmental zooplankton and phytoplankton, bronopol products must be heavily diluted before being discarded, thus increasing usage costs significantly. New and effective anti-saprolegniasis drugs are urgently needed.

During the course of our screening for selective anti-S. parasitica compounds from actinomycete cultural broths, we discovered five new angucycline-type antibiotics, namely saprolmycins A (1), B (2), C
(3), D (4) and E (5). In our study, these five compounds all exhibited selective activities, with A (1) and E (5) exhibiting exceptional potency and selectivity as potential anti-S. parasitica compounds. We report herein the isolation, structure elucidation and biological effects of saprolmycins.

\section{MATERIALS AND METHODS}

General experimental procedures

All reagents in our experiments were purchased from Wako Pure Chemical Industries, Osaka, Japan. Optical rotations were measured with a DIP-1000 digital polarimeter (JASCO, Tokyo, Japan). NMR spectra were measured using a JNM-ECA-600 NMR spectrometer (JEOL, Tokyo, Japan) with tetramethylsilane as an internal standard in $\mathrm{CDCl}_{3}$ or $\mathrm{CD}_{3} \mathrm{OD}$. HPLC analysis was carried out using a HPLC pump GL-7410 and a PDA detector GL-7452 (GL Science, Tokyo, Japan). For HPLC fractionations, a HPLC pump L-6200 (Hitachi, Tokyo, Japan) and a UV detector L-4200 (Hitachi) were used. IR spectra were recorded on a FT/IR-8600 spectrometer (Shimadzu, Kyoto, Japan). HR-FAB-MS spectra were measured on a JMS-700T tandem mass spectrometer (JEOL). ESI-MS spectra were measured with an API-3200 triple quadrupole mass spectrometer (Applied Biosystems, Tokyo, Japan). UV-vis spectra were measured with a V-630 spectrophotometer (JASCO). Optical densities were measured with a microplate reader SH-1000 Lab (Corona, Hitachinaka, Japan). Melting points were measured with MP-J3 (Yanaco, Kyoto, Japan).

\section{Organisms}

The strain TK08046 was isolated from a soil sample collected at Shizuoka City, Japan, which we classified as Streptomyces sp. using $16 \mathrm{~S}$ rDNA sequence analysis with $1516 \mathrm{bp}$ of the genome (gene accession no. AB67946). The primers 10F (5'-GTTTGATCCTGGCTCA-3'), 686F (5'-TAGCGGTGAAATGC GTAGA-3' $\left.{ }^{\prime}\right)$, 800R ( $5^{\prime}$-TACCAGGGTATCTAATCC- $\left.3^{\prime}\right)$, 1541R (5'-AAGGAGGT GATCCAGCC-3') were used for amplification of the almost complete $16 \mathrm{~S}$ 
ribosomal DNA gene. TK08046 was deposited in the culture collection of NITE Biological Resource Center (Chiba, Japan) as NITE P-1138. For maintenance, the strain was grown on starch casein agar slant $(1.0 \%$ starch, $0.03 \%$ casein, $0.2 \% \mathrm{NaCl}, 0.2 \% \mathrm{~K}_{2} \mathrm{HPO}_{4}, 0.005 \% \mathrm{MgSO}_{4}, 0.002 \% \mathrm{CaCO}_{3}, 0.001 \% \mathrm{FeSO}_{4}$, $\mathrm{pH}$ 7.2) containing $1.5 \%$ of agar.

\section{Fermentation}

A loop of spores of the strain were inoculated into starch casein medium $(10 \mathrm{ml})$ in a test tube, and incubated for 5 days at $30^{\circ} \mathrm{C}$ on a reciprocal shaker (120 r.p.m.). The seed-culture was transferred into $200 \mathrm{ml}$ starch casein medium in a Sakaguchi flask (60 flasks, total 121) and incubated for 7 days at $30^{\circ} \mathrm{C}$ on a reciprocal shaker ( 120 r.p.m.).

\section{Isolation}

The cultured broth (12l) was filtered and the filtrate was extracted with EtOAc (121). The organic layer was concentrated to dryness and $717.9 \mathrm{mg}$ of the residue was obtained. The extract was dissolved in $\mathrm{MeOH}$ and the solution was applied to an octadecylsilane (ODS) column (Wakogel $50 \mathrm{C}_{18}$, i.d. $30 \times 150 \mathrm{~mm}$ ) It was eluted with a stepwise gradient of $\mathrm{H}_{2} \mathrm{O}-\mathrm{CH}_{3} \mathrm{CN}(30,50,70,90$ and $100 \%)$ and fractionated. Active fractions of $50-90 \% \mathrm{CH}_{3} \mathrm{CN}$ eluate were combined and concentrated in vacuo to yield a crude material $(329.2 \mathrm{mg})$. Further purification was carried out using a HPLC ODS column (Cosmosil 5C 18 -AR-II, i.d. $10 \times 250 \mathrm{~mm}$, detection $230 \mathrm{~nm}$, flow rate $2.5 \mathrm{ml} \mathrm{min}^{-1}$ ) with $60 \% \mathrm{CH}_{3} \mathrm{CN}$ isocratic elution. The effluent was divided into several fractions and each fraction was bioassayed. Five peak fractions covering the beginning to the end of each peak were active and were evaporated under reduced pressure to give the five purified active compounds, saprolmycin A (1: retention time (r.t.) = $8.96 \mathrm{~min}, 3.1 \mathrm{mg})$, B (2: r.t. $=11.27 \mathrm{~min}, 5.9 \mathrm{mg})$, C (3: r.t. $=11.96 \mathrm{~min}, 10.6 \mathrm{mg})$, D (4: r.t. $=15.99 \mathrm{~min}, 14.9 \mathrm{mg})$ and $\mathrm{E}($ 5: r.t. $=16.96 \mathrm{~min}, 60.1 \mathrm{mg})$.

\section{Complete and partial hydrolysis of 5}

Antibiotic 5 was degraded completely ${ }^{14}$ or partially ${ }^{15}$ by using acid hydrolysis. $5\left(30.3 \mathrm{mg}\right.$ ) was completely hydrolyzed with $0.5 \mathrm{M} \mathrm{H}_{2} \mathrm{SO}_{4}$ for $1 \mathrm{~h}$ at $80^{\circ} \mathrm{C}$. An aglycon $(7: 7.0 \mathrm{mg})$ was obtained from the reaction mixture by EtOAc extraction and further purification on a HPLC ODS column (Cosmosil $5 \mathrm{C}_{18}$-AR-II, i.d. $10 \times 250 \mathrm{~mm}$, detection $230 \mathrm{~nm}$, flow rate $2.5 \mathrm{ml} \mathrm{min}^{-1}$ ) with $20 \% \mathrm{CH}_{3} \mathrm{CN}$ isocratic elution.

Antibiotic 5 (20.2 mg) was partially hydrolyzed with $\mathrm{CH}_{3} \mathrm{CN}-0.2 \%$ phosphoric acid (60:40) for $1 \mathrm{~h}$ at $40{ }^{\circ} \mathrm{C}$, and extracted with $\mathrm{CHCl}_{3}$. The organic solvent layer was dried in vacuo and it was purified on a HPLC ODS column (Cosmosil 5C 18 -AR-II, i.d. $10 \times 250 \mathrm{~mm}$, detection $230 \mathrm{~nm}$, flow rate $2.5 \mathrm{ml} \mathrm{min}^{-1}$ ) using $30 \% \mathrm{CH}_{3} \mathrm{CN}$ isocratic elution to yield a partial hydrolysate (8: $12.2 \mathrm{mg})$.

\section{Measurement of biological activities}

S. parasitica was cultured on glucose yeast extract agar medium $(0.25 \%$ yeast extract, $0.25 \%$ glucose, $1.5 \%$ agar, $\mathrm{pH} 6.0$ ) for 7 days at $16{ }^{\circ} \mathrm{C}$. A spore suspension was prepared by using a modified method reported by Heath and Greenwood. ${ }^{16}$ The spore suspension $\left(10^{3}\right.$ spores $\left.\mathrm{ml}^{-1}, 100 \mu \mathrm{l}\right)$, quadruple concentration of glucose yeast extract medium $(50 \mu \mathrm{l})$ and a serial double diluted sample solution in $8 \% \mathrm{MeOH}-\mathrm{H}_{2} \mathrm{O}(50 \mu \mathrm{l})$ were poured into wells of 96 -well plate and incubated for $24 \mathrm{~h}$ at $16^{\circ} \mathrm{C}$. A solution of malachite green $\left(0.25 \mu \mathrm{g} \mathrm{ml}^{-1}\right)$ was used as a positive control. The growth of vegetative hyphae was observed microscopically (Olympus, CK2) and the MIC of the sample was determined.

Anti-bacterial activities against Bacillus subtilis, Escherichia coli, Pseudomonas putida and Staphylococcus aureus were determined using the conventional paper disc method with Luria-Bertani agar medium inoculated with each bacterium. Anti-yeast and anti-fungal activities were measured using a method similar to that for the anti-S. paracitica assay using a cell suspension of Saccharomyces cerevisiae $\left(2.0 \times 10^{4}\right.$ cells ml $\left.{ }^{-1}\right)$ and a mycelial suspension of Phoma sp. in distilled water. Phoma sp. was cultured in Sabouraud agar medium, a piece of the agar medium $\left(1 \mathrm{~cm}^{2}\right)$ containing its vegetative hypha was crushed with distilled water to make a mycelial suspension. The S. cerevisiae suspension $(100 \mu \mathrm{l})$ and quadruple concentration of the yeast extract peptone D-glucose medium ( $4 \%$ yeast extract, $8 \%$ peptone, $8 \%$ glucose, $\mathrm{pH} 6.5,50 \mu \mathrm{l}$ ), Phoma sp. suspension $(100 \mu \mathrm{l})$ and Sabouraud medium $(50 \mu \mathrm{l})$ were mixed separately with a serial double diluted sample solution in $8 \% \mathrm{MeOH}-\mathrm{H}_{2} \mathrm{O}(50 \mu \mathrm{l})$ in wells of $96-$-well plate and incubated for $24 \mathrm{~h}$ at $30^{\circ} \mathrm{C}$. A solution of cycloheximide $\left(25 \mu \mathrm{g} \mathrm{ml}^{-1}\right)$ was used as a positive control. Anti-S. cerevisiae and Phoma sp. activities were observed microscopically, and the MICs of the samples were determined.

Synechocystis sp. and Chlorella kessleri were cultured in BG-11 medium and CA medium, respectively, under a light intensity of $25 \mu \mathrm{mol}$ photons $\mathrm{m}^{-2} \mathrm{~s}^{-1}$ with a $16: 8 \mathrm{~h}$ light:dark cycle at $25^{\circ} \mathrm{C}$. Algal cells in logarithmic growth phase were used for the assay. Synechocystis sp. suspension $(100 \mu \mathrm{l})$ and BG-11 medium $(50 \mu \mathrm{l})$ and $C$. kessleri suspension $(100 \mu \mathrm{l})$ and CA medium $(50 \mu \mathrm{l})$ were mixed separately with a serial double diluted sample solution in $8 \%$ $\mathrm{MeOH}-\mathrm{H}_{2} \mathrm{O}(50 \mu \mathrm{l})$ in wells of 96 -well plate and incubated for 7 days at $25^{\circ} \mathrm{C}$ under the same light conditions. A solution of cycloheximide $\left(25 \mu \mathrm{g} \mathrm{ml}^{-1}\right)$ was used as a positive control. Anti-algal activities were observed microscopically and the algal growth was monitored using OD methods, and was determined to be $680 \mathrm{~nm}$ with a microplate reader.

The water flea, Daphnia pulex, was isolated from a pond in Ritsumeikan University. D. pulex was cultured using C. kessleri as a food source in clean water under a light intensity of $10 \mu \mathrm{mol}$ photons $\mathrm{m}^{-2} \mathrm{~s}^{-1}$ with a $16: 8 \mathrm{~h}$ light:dark cycle at $18-20^{\circ} \mathrm{C}$. Five offspring born within $24 \mathrm{~h}$ were added to a serial 10 -fold diluted sample solution (final $1 \% \mathrm{MeOH}, 10 \mathrm{ml}$ ) and incubated for $24 \mathrm{~h}$ using the above-mentioned conditions. Mortalities were counted, and the value of $\mathrm{LD}_{50}$ was estimated using a probit model and the statistic software, SPSS (IBM, Tokyo, Japan).

\section{RESULTS AND DISCUSSION}

\section{Taxonomy of the producing strain TK08046}

Strain TK08046 was isolated from a soil sample collected in Shizuoka City, Japan. The vegetative mycelia developed well on starch casein, Bennet, glucose yeast extract and Luria-Bertani agar plates. The color of vegetative mycelia was dark orange and the color of mature spore was white on starch casein agar. On the other agar plates, the mycelia and the spore showed pale dark orange and white, respectively. 16S rDNA region were amplified and sequenced by using representative primers. Almost complete $16 \mathrm{~S}$ rDNA gene (1516bp) was sequenced and used for the identification. Comparison of the sequence with known sequences of Streptomyces sp. in GeneBank database was carried out by the BLAST search. The BLAST result showed that the $16 \mathrm{~S}$ rDNA sequence of the strain had 99.5 and $99.3 \%$ sequence similarities with Streptomyces roseogriseus NBRC13681 and Streptomyces canaries NBRC13431, respectively. Therefore, the strain TK08046 was classified as a Streptomyces species.

\section{Isolation and characterization}

The fermentation was performed in starch casein medium with aeration, and the filtered culture broth (12l) was extracted with EtOAc (12l) and the organic layer was evaporated to dryness $(717.9 \mathrm{mg})$. The acquired crude extract was applied to an ODS column and the fractions were eluted with a stepwise gradient of $\mathrm{H}_{2} \mathrm{O}-\mathrm{CH}_{3} \mathrm{CN}$. The fractions of $50-90 \% \mathrm{CH}_{3} \mathrm{CN}$ eluate were combined and concentrated in vacuo to yield a crude material $(329.2 \mathrm{mg})$. Further purification was carried out with a HPLC ODS column to obtain five active compounds, saprolmycin A (1: r.t. $=8.96 \mathrm{~min}, 3.1 \mathrm{mg}), \mathrm{B}(2:$ r.t. $=11.27 \mathrm{~min}$, $5.9 \mathrm{mg})$, C (3: r.t. $=11.96 \mathrm{~min}, 10.6 \mathrm{mg})$, D (4: r.t. $=15.99 \mathrm{~min}$, $14.9 \mathrm{mg}$ ) and $\mathrm{E}(5$ : r.t. $=16.96 \mathrm{~min}, 60.1 \mathrm{mg})$. All compounds were dark-yellow powder and soluble in $\mathrm{MeOH}$, EtOAc and $\mathrm{CHCl}_{3}$, but insoluble in water and $n$-hexane. The UV-vis and IR data of these compounds closely resembled each other, which indicated they were analogs containing the same chromophore. The physicochemical properties of these compounds are listed in Table 1.

\section{Structure determination}

Saprolmycin E (5). Comprehensive analyses of 2D NMR spectra (COSY, HMQC, HMBC and ROESY) conducted on the compounds 
Table 1 Physicochemical properties of saprolmycin A (1)-E (5), aglycon (7) and partial hydrolysate (8)

\begin{tabular}{|c|c|c|c|c|c|c|c|}
\hline & 1 & 2 & 3 & 4 & 5 & 7 & 8 \\
\hline Appearance & Dark yellow powder & Dark yellow powder & Dark yellow powder & Dark yellow powder & Dark yellow powder & Dark yellow powder & Dark yellow powder \\
\hline ESI-MS (m/z) & 705 [M-H] ${ }^{-}$ & 707 [M-H] ${ }^{-}$ & 705 [M-H] ${ }^{-}$ & $821[\mathrm{M}-\mathrm{H}]^{-}$ & 819 [M-H] ${ }^{-}$ & $485[\mathrm{M}-\mathrm{H}]^{-}$ & $595[\mathrm{M}-\mathrm{H}]^{-}$ \\
\hline \multicolumn{8}{|c|}{$H R-F A B-M S(m / z)$} \\
\hline Found & $\begin{array}{l}713.2407 \\
{[\mathrm{M}+\mathrm{Li}]^{+}}\end{array}$ & $\begin{array}{l}715.2603 \\
{\left[\mathrm{M}+\mathrm{Li}^{+}\right.}\end{array}$ & $\begin{array}{l}713.2407 \\
{\left[\mathrm{M}+\mathrm{Li}^{+}\right.}\end{array}$ & $\begin{array}{l}829.3266 \\
{[\mathrm{M}+\mathrm{Li}]^{+}}\end{array}$ & $\begin{array}{l}827.3089 \\
{[\mathrm{M}+\mathrm{Li}]^{+}}\end{array}$ & $485.1451\left[^{[M-H}\right]^{-}$ & $595.1811[\mathrm{M}-\mathrm{H}]^{-}$ \\
\hline $\begin{array}{l}\text { Molecular } \\
\text { formula }\end{array}$ & $\mathrm{C}_{37} \mathrm{H}_{38} \mathrm{O}_{14}$ & $\mathrm{C}_{37} \mathrm{H}_{40} \mathrm{O}_{14}$ & $\mathrm{C}_{37} \mathrm{H}_{38} \mathrm{O}_{14}$ & $\mathrm{C}_{43} \mathrm{H}_{50} \mathrm{O}_{16}$ & $\mathrm{C}_{43} \mathrm{H}_{48} \mathrm{O}_{16}$ & $\mathrm{C}_{25} \mathrm{H}_{26} \mathrm{O}_{10}$ & $\mathrm{C}_{31} \mathrm{H}_{32} \mathrm{O}_{12}$ \\
\hline $\begin{array}{l}\text { UV } \lambda_{\max } \\
(\mathrm{MeOH}) \mathrm{nm} \\
(\log \varepsilon)\end{array}$ & $\begin{array}{c}217(4.65), 317 \\
(3.85), 425 \text { (3.78) }\end{array}$ & $\begin{array}{c}218(4.62), 315 \\
(3.85), 423(3.89)\end{array}$ & $\begin{array}{c}218(4.65), 316 \\
(3.86), 425(3.79)\end{array}$ & $\begin{array}{c}219(4.68), 316 \\
(3.91), 429(3.88)\end{array}$ & $\begin{array}{c}217(4.67), 318 \\
(3.88), 427(3.90)\end{array}$ & $\begin{array}{c}219(4.36), 319 \\
(3.77), 429(3.69)\end{array}$ & $\begin{array}{c}219(4.78), 320 \\
(3.96), 432(3.99)\end{array}$ \\
\hline $\begin{array}{l}\text { IR } v_{\max } \\
\text { (film) } \mathrm{cm}^{-1}\end{array}$ & $1732,1699,1639$ & 1732, 1701, 1639 & $1734,1701,1643$ & $1732,1701,1641$ & 1730, 1701, 1639 & $1718,1683,1645$ & $1718,1684,1645$ \\
\hline
\end{tabular}

revealed significant similarities and differences discussed herein. The structural elucidation of a major component $\mathbf{5}$ was carried out at first. The molecular formula of 5 was elucidated to be $\mathrm{C}_{43} \mathrm{H}_{48} \mathrm{O}_{16}$ from HR-FAB-MS data (found $\mathrm{m} / z$ 827.3089 $[\mathrm{M}+\mathrm{Li}]^{+}$, calcd. 827.3102 $\left.[\mathrm{M}+\mathrm{Li}]^{+}\right)$. The molecular formula coincided with that of saquayamycin A (6), an angucycline antibiotic that consists of three sugar moieties, a rhodinose and two aculoses, and an aglycon containing benz[a]anthraquinone chromophore and a characteristic saturated pyran ring. All spectroscopic data (IR, UV-vis, and ${ }^{1} \mathrm{H}$ NMR) of $\mathbf{5}$ were also similar to those of $6 .{ }^{15}$ In the ${ }^{13} \mathrm{C}$ NMR spectrum of $\mathbf{5}$, many signals were observed with $<1$ p.p.m. variation from published data of 6; however, chemical shifts of four signals at around 90-100 p.p.m. seemed to be somewhat different. By detailed comparison of the data, chemical shifts of two carbon signals at $\delta_{\mathrm{C}} 88.4$ and 98.9 p.p.m. in 5 were considered to be observed with a difference of 4.0 and 3.6 p.p.m., respectively, from reported chemical shifts $\left(\delta_{\mathrm{C}} 92.4\right.$ and 95.3 p.p.m.) in 6. These two carbons in 6 were attributed to anomeric carbons.

The ${ }^{1} \mathrm{H}$ NMR spectrum of $\mathbf{5}$ suggested the existence of the same aglycon in $\mathbf{6}$, that is, a hydrogen bonding phenolic hydroxyl group $8-\mathrm{OH}\left(\delta_{\mathrm{H}} 12.30\right)$; three exchangeable hydroxy groups, 4a-OH $\left(\delta_{\mathrm{H}}\right.$ $3.69), 12 \mathrm{~b}-\mathrm{OH}\left(\delta_{\mathrm{H}} 4.57\right)$ and $3^{\prime}-\mathrm{OH}\left(\delta_{\mathrm{H}} 4.93\right)$; and four aromatic protons, $\mathrm{H}-5\left(\delta_{\mathrm{H}} 6.39\right), \mathrm{H}-6\left(\delta_{\mathrm{H}} 6.89\right), \mathrm{H}-11\left(\delta_{\mathrm{H}} 7.59\right)$ and $\mathrm{H}-10\left(\delta_{\mathrm{H}}\right.$ 7.86). To confirm the structure and the absolute configuration of the aglycon, 5 was hydrolyzed with $0.5 \mathrm{M} \mathrm{H}_{2} \mathrm{SO}_{4}$ for $1 \mathrm{~h}$ at $80^{\circ} \mathrm{C}$ and an aglycon (7) was obtained. The physicochemical properties and NMR data of 7 were listed in Tables 1 and 2, respectively. 7 was identified to be the aglycon of $\mathbf{6}$ including stereochemistry by comparison with published ${ }^{1} \mathrm{H} \mathrm{NMR}^{14}$ and optical rotation data (lit., ${ }^{15}[\alpha]_{\mathrm{D}}{ }^{28}+151, c$ 0.2 , dioxane). The structure of 7 was displayed in Figure $3 .{ }^{1} \mathrm{H}$ and ${ }^{13} \mathrm{C}$ NMR signals of the aglycon in $\mathbf{5}$ were distinguished by COSY and HMBC data summarized in Figure 1.

Remaining NMR signals of $\mathbf{5}$ were three methyl, two methylene, four oxygenated methine, three anomeric and four olefinic methine proton and carbon signals, and two ketone carbon ones. COSY and HMBC data of 5 revealed three sugar moieties of two kinds of 2, 3, 6trideoxyhexoses. An existence of a rhodinose or an amicetose, of which 4-hydroxyl and 6-methyl groups were cis or trans configuration, respectively, was indicated by tracing COSY correlations summarized in Figure 1. A rhodinose was strongly suggested by a small coupling constant $(J=1.5 \mathrm{~Hz})$ between $\mathrm{H}^{\prime \prime}-4$ and $\mathrm{H}^{\prime \prime}-5$ protons, because large value as axial-axial coupling was expected and indeed $J=8.5 \mathrm{~Hz}$ was observed in an amicetose in landomycin. ${ }^{17}$ Two aculoses containing $\alpha, \beta$-unsaturated ketone were uncovered by the combination of COSY and HMBC data summarized in Figure 1. Thus, four components, an aglycon, a rhodinose and two aculose moieties were disclosed and these partial resolved structures of 5 were identical to the components of $\mathbf{6}$.

The difference between 5 and $\mathbf{6}$ is the linkage order of sugars and the aglycon. The central HMBC correlations establishing connections among the three sugars and the aglycon were follows; the rhodinose connected to $\mathrm{C}-4^{\prime}-\mathrm{OH}$ of the aglycon pyran $\left(\mathrm{H}-1^{\prime \prime}\right.$ to $\left.\mathrm{C}-4^{\prime}\right)$, an aculose connected to $\mathrm{C}-4^{\prime \prime}-\mathrm{OH}$ of the rhodinose $\left(\mathrm{H}-1^{\prime \prime \prime}\right.$ to $\left.\mathrm{C}-4^{\prime \prime}\right)$, and a second aculose connected to $\mathrm{C}-3-\mathrm{OH}$ of the aglycon chromophore $\left(\mathrm{H}-1^{\prime \prime \prime \prime}\right.$ to $\left.\mathrm{C}-3\right)$, that is, a disaccharide (aculosylrhodinose) and an aculose connected to the aglycon pyran and chromophore, respectively. These connections were also supported by ROESY correlation data as shown in Figure 2, thus the structure of $\mathbf{5}$ was determined as shown in Figure 3. In the case of 6, a disaccharide (aculosylrhodinose) and an aculose connected to opposite positions of the aglycon, and the differences of chemical shifts of anomeric carbons in $\mathbf{5}$ and $\mathbf{6}$ should be caused by these structural differences.

In order to confirm the structure, $\mathbf{5}$ was partially hydrolyzed with $\mathrm{CH}_{3} \mathrm{CN}-0.2 \%$ phosphoric acid for $1 \mathrm{~h}$ at $40^{\circ} \mathrm{C}$ to yield a partial hydrolysate (8). The physicochemical properties as shown Table 1 and ${ }^{1} \mathrm{H}$ NMR data of 8 suggested the lack of the disaccharide aculosylrhodinose moiety from 5 . The aglycon pyran C-4' signal was observed at $\delta_{\mathrm{C}} 77.5$ in the ${ }^{13} \mathrm{C}$ NMR spectrum of 8 , which was higher than that $\left(\delta_{\mathrm{C}} 88.4\right)$ in 5 , also indicated the lack of the disaccharide. 2D NMR analyses of 8 summarized in Figure 4 demonstrated the connection between an aculose to C-3 of the aglycon chromophore via a glycosidic bond. The structure of $\mathbf{5}$ was established by that of $\mathbf{8}$ because an aculose could connect to only one moiety via a glycosidic bond and thus should be the non-reducing end of the disaccharide in $\mathbf{5}$. 
Table 2 Assignments of ${ }^{1} \mathrm{H}$ and ${ }^{13} \mathrm{C}$ NMR signals of saprolmycin E (5), saquayamycin A (6), aglycon (7) and partial hydrolysate (8)

\begin{tabular}{|c|c|c|c|c|c|c|c|c|}
\hline \multirow[b]{2}{*}{ Position } & \multicolumn{2}{|r|}{$5^{a}$} & \multicolumn{2}{|r|}{$6^{\mathrm{b}}$} & \multicolumn{2}{|r|}{$7^{c}$} & \multicolumn{2}{|r|}{$8^{c}$} \\
\hline & $\delta_{C}$ & $\delta_{H}($ mult, J in $\mathrm{Hz}$ ) & $\delta_{C}$ & $\delta_{H}($ mult, J in $H z)$ & $\delta_{C}$ & $\delta_{H}($ mult, J in $H z)$ & $\delta_{C}$ & $\delta_{H}($ mult, J in $\mathrm{Hz})$ \\
\hline 1 & 203.6 & & 204.7 & & 208.0 & & 205.8 & \\
\hline 2 & 49.7 & $\begin{array}{c}2.53(d, 13.0) \\
3.20(d d, 3.4,13.0)\end{array}$ & 50.2 & $\begin{array}{l}2.51(\mathrm{~d}) \\
3.18(\mathrm{dd})\end{array}$ & 54.3 & $\begin{array}{c}2.65(\mathrm{~d}, 13.1) \\
2.82(\mathrm{~d}, 3.4,13.1)\end{array}$ & 50.6 & $\begin{array}{c}2.73(\mathrm{~d}, 13.1) \\
2.90(\mathrm{dd}, 3.4,13.1)\end{array}$ \\
\hline 3 & 82.3 & & 82.4 & & 78.7 & & 82.6 & \\
\hline 4 & 42.1 & $\begin{array}{c}1.80(d, 15.1) \\
2.44(d d, 3.4,15.1)\end{array}$ & 44.5 & $\begin{array}{l}1.85(\mathrm{~d}) \\
2.29(\mathrm{dd})\end{array}$ & 45.7 & $\begin{array}{l}1.99(d, 15.0) \\
2.03(d, 15.0)\end{array}$ & 41.4 & $\begin{array}{c}1.94(\mathrm{~d}, 15.8) \\
2.43(\mathrm{dd}, 2.8,15.8)\end{array}$ \\
\hline $4 a$ & 78.8 & & 79.9 & & 79.7 & & 79.4 & \\
\hline $4 \mathrm{a}-\mathrm{OH}$ & & 3.69 (brs) & & & & & & \\
\hline 5 & 144.8 & $6.39(d, 9.6)$ & 145.6 & $6.46(d)$ & 147.3 & $6.37(\mathrm{~d}, 9.6)$ & 146.1 & $6.38(d, 9.6)$ \\
\hline 6 & 116.9 & $6.89(\mathrm{~d}, 9.6)$ & 117.4 & $6.91(d)$ & 119.2 & $6.84(d, 9.6)$ & 116.5 & $6.85(d, 9.6)$ \\
\hline $6 a$ & 138.0 & & 138.8 & & 141.4 & & 139.0 & \\
\hline 7 & 187.6 & & 188.2 & & 190.8 & & 188.9 & \\
\hline $7 a$ & 113.4 & & 114.0 & & 116.4 & & 114.6 & \\
\hline 8 & 157.6 & & 158.0 & & 159.8 & & 158.0 & \\
\hline $8-\mathrm{OH}$ & & 12.3 (brs) & & $12.29(\mathrm{~s})$ & & & & \\
\hline 9 & 138.1 & & 138.2 & & 140.3 & & 138.6 & \\
\hline 10 & 133.2 & $7.86(d, 7.6)$ & 133.5 & 7.88 & 135.6 & $7.83(d, 7.6)$ & 133.3 & $7.84(d, 7.6)$ \\
\hline 11 & 119.3 & $7.59(\mathrm{~d}, 7.6)$ & 119.6 & 7.61 & 121.0 & $7.59(\mathrm{~d}, 7.6)$ & 118.9 & $7.56(d, 7.6)$ \\
\hline $11 a$ & 129.9 & & 130.5 & & 133.2 & & 131.6 & \\
\hline 12 & 181.8 & & 182.2 & & 184.6 & & 182.9 & \\
\hline $12 a$ & 138.2 & & 138.9 & & 140.9 & & 139.3 & \\
\hline $12 b$ & 76.7 & & 77.4 & & 83.1 & & 70.3 & \\
\hline $12 \mathrm{~b}-\mathrm{OH}$ & & 4.57 (brs) & & & & & & \\
\hline 13 & 26.0 & $1.45(\mathrm{~s})$ & 25.5 & $1.41(\mathrm{~s})$ & 31.2 & $1.20(\mathrm{~s})$ & 26.3 & 1.39 (s) \\
\hline $1^{\prime}$ & 70.5 & $4.83(\mathrm{dd}, 1.4,10.3)$ & 71.1 & $4.89(\mathrm{dd})$ & 73.5 & $4.77(\mathrm{~d}, 11.0)$ & 71.1 & $4.85(\mathrm{~m})$ \\
\hline $2^{\prime}$ & 38.2 & $\begin{array}{c}1.36(\mathrm{dd}, 5.2,13.1) \\
2.49(\mathrm{ddd}, 1.4,5.2,13.1)\end{array}$ & 38.9 & $\begin{array}{c}1.38-1.48(\mathrm{~m}) \\
2.57(\mathrm{ddd})\end{array}$ & 42.1 & $\begin{array}{c}1.34(\mathrm{~m}) \\
2.41(\mathrm{ddd}, 1.4,5.2,11.0)\end{array}$ & 38.2 & $\begin{array}{c}1.30(\mathrm{~m}) \\
2.40(\mathrm{ddd}, 2.1,4.8,13.1)\end{array}$ \\
\hline $3^{\prime}$ & 70.9 & $3.79(\mathrm{~m})$ & 71.3 & $3.91(\mathrm{dddd})$ & 74.7 & $3.69(\mathrm{~m})$ & 72.4 & $3.67(\mathrm{~m})$ \\
\hline $3^{\prime}-\mathrm{OH}$ & & 4.93 (brs) & & $4.26(d)$ & & & & \\
\hline $4^{\prime}$ & 88.4 & $3.04(\mathrm{~m})$ & 89.3 & $3.21(\mathrm{dd})$ & 79.8 & $3.02(t, 9.6)$ & 77.5 & $3.01(t, 8.9)$ \\
\hline $5^{\prime}$ & 74.0 & $3.54(\mathrm{~m})$ & 74.4 & $3.58(\mathrm{dq})$ & 78.8 & $3.41(\mathrm{~m})$ & 76.4 & $3.42(\mathrm{~m})$ \\
\hline $6^{\prime}$ & 18.0 & $1.34(\mathrm{~d}, 6.2)$ & 18.4 & $1.39(\mathrm{~d})$ & 19.6 & $1.35(\mathrm{~d}, 6.8)$ & 17.5 & $1.34(\mathrm{~d}, 6.2)$ \\
\hline $1^{\prime \prime}$ & 98.9 & 4.97 (brs) & 95.2 & $5.38(d, 3.5)$ & & & 88.5 & $5.64(d, 4.1)$ \\
\hline $2^{\prime \prime}$ & 23.8 & $\begin{array}{l}1.68(\mathrm{~m}) \\
2.10(\mathrm{~m})\end{array}$ & 142.1 & $6.85(\mathrm{dd})$ & & & 145.3 & $6.85(\mathrm{dd}, 4.5,10.3)$ \\
\hline $3^{\prime \prime}$ & 24.6 & $\begin{array}{l}1.93(\mathrm{~m}) \\
2.08(\mathrm{~m})\end{array}$ & 127.3 & $6.15(d, 10.2)$ & & & 126.5 & $5.97(d, 10.3)$ \\
\hline $4^{\prime \prime}$ & 75.6 & 3.69 (brs) & 195.1 & & & & 198.4 & \\
\hline $5^{\prime \prime}$ & 67.3 & $4.22(\mathrm{dq}, 1.5,6.8)$ & 71.6 & $4.76(q)$ & & & 70.2 & $4.68(q, 6.9)$ \\
\hline $6^{\prime \prime}$ & 16.5 & $1.25(\mathrm{~d}, 6.8)$ & 15.2 & $1.45(d)$ & & & 14.5 & $1.32(\mathrm{~d}, 6.9)$ \\
\hline $1^{\prime \prime \prime}$ & 94.8 & $5.24(\mathrm{~d}, 3.4)$ & 92.4 & $5.26(\mathrm{brd})$ & & & & \\
\hline $2^{\prime \prime \prime}$ & 142.2 & $6.86(d d, 3.4,10.3)$ & 24.7 & $\begin{array}{l}1.49(\mathrm{~m}) \\
2.04(\mathrm{~m})\end{array}$ & & & & \\
\hline $3^{\prime \prime \prime}$ & 127.0 & $6.04(d, 10.3)$ & 24.5 & $\begin{array}{l}1.90(\mathrm{~m}) \\
1.92(\mathrm{~m})\end{array}$ & & & & \\
\hline $4^{\prime \prime \prime}$ & 196.1 & & 76.2 & $3.70(\mathrm{ddd})$ & & & & \\
\hline $5^{\prime \prime \prime}$ & 70.2 & $4.55(q, 6.9)$ & 67.0 & $4.25(\mathrm{dq})$ & & & & \\
\hline $6^{\prime \prime \prime}$ & 14.6 & $1.41(\mathrm{~d}, 6.9)$ & 17.1 & $1.29(\mathrm{~d})$ & & & & \\
\hline $1^{\prime \prime \prime \prime}$ & 88.2 & $5.57(d, 4.1)$ & 95.3 & $5.27(\mathrm{~d}, 3.5)$ & & & & \\
\hline $2^{\prime \prime \prime \prime}$ & 142.4 & $6.67(\mathrm{dd}, 4.1,10.3)$ & 143.0 & $6.89(\mathrm{dd})$ & & & & \\
\hline $3^{\prime \prime \prime \prime}$ & 127.1 & $6.09(d, 10.3)$ & 127.3 & $6.09(\mathrm{~d}, 10.2)$ & & & & \\
\hline $4^{\prime \prime \prime \prime}$ & 196.3 & & 196.7 & & & & & \\
\hline $5^{\prime \prime \prime \prime}$ & 70.1 & $4.71(q, 6.2)$ & 70.7 & $4.55(q)$ & & & & \\
\hline $6^{\prime \prime \prime \prime}$ & 14.7 & $1.37(\mathrm{~d}, 6.2)$ & 15.1 & $1.37(\mathrm{~d})$ & & & & \\
\hline
\end{tabular}




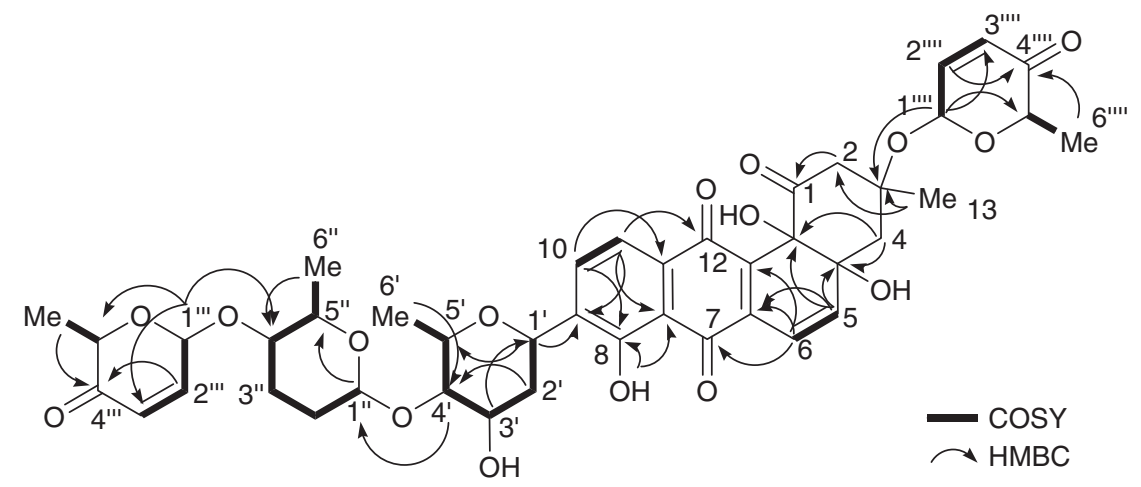

Figure 1 Summarized COSY and HMBC correlations of saprolmycin E (5).

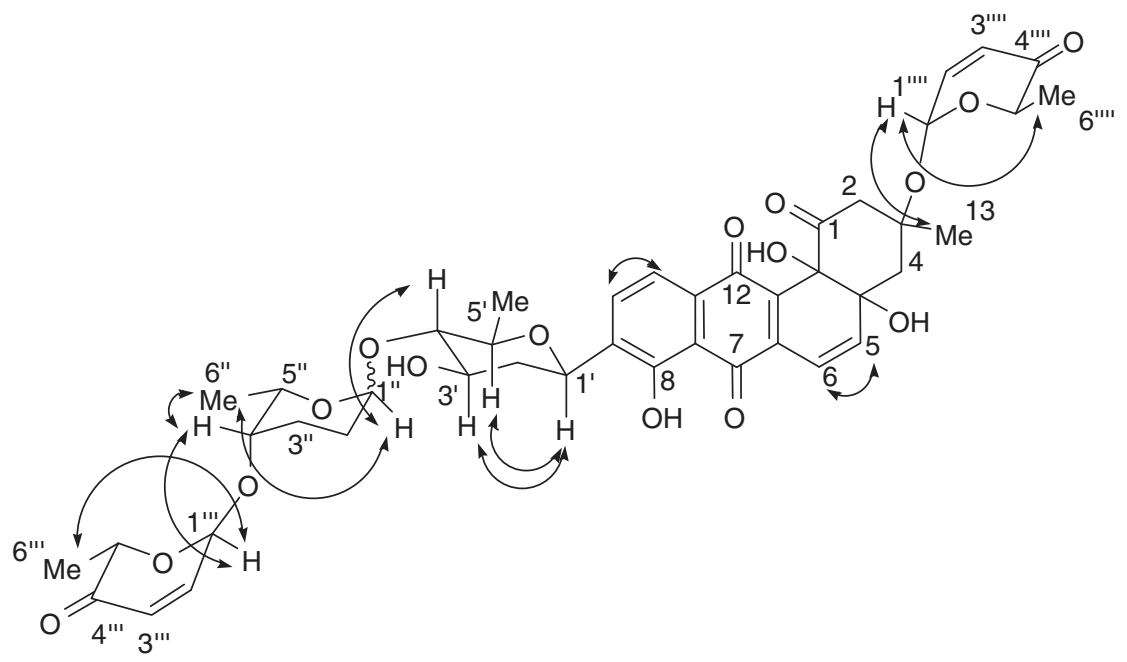

Figure 2 Selected ROESY correlations of saprolmycin E (5).

The glycosidic bonds of two aculoses in 5 should be $\beta$-form because $J$ values of aculose anomeric $\alpha$-protons in $\mathbf{6}^{15}$ and P-1894B ${ }^{14}$ were reported to be $3.4 \mathrm{~Hz}$ and the $J$ values of those in 5 were 3.4 and $4.1 \mathrm{~Hz}$. The total assignments of ${ }^{1} \mathrm{H}$ and ${ }^{13} \mathrm{C}$ NMR signals of 5 were demonstrated in Table 2. The structures of 1-4 isolated as minor components from the same fermented broth were determined by comparisons of spectral data with those of $\mathbf{5}$ and each other.

Saprolmycin D (4). The ESI-MS spectrum of 4 showed a pseudomolecular ion peak [M-H] ${ }^{-}$at $m / z 821$, the UV-vis and IR data of 4 as shown in Table 1 closely resembled those of 5 and $6 .{ }^{15}$ The molecular formula of 4 was determined to be $\mathrm{C}_{43} \mathrm{H}_{50} \mathrm{O}_{16}$ from its HRFAB-MS data (found $\mathrm{m} / \mathrm{z} 829.3266[\mathrm{M}+\mathrm{Li}]^{+}$, calcd. $\mathrm{m} / \mathrm{z} 829.3259$ $\left.[\mathrm{M}+\mathrm{Li}]^{+}\right)$, and it revealed that 4 should be a dihydro derivative of 5 from their molecular formulas. The signals of the aglycon, an aculose and a rhodinose were observed in ${ }^{1} \mathrm{H}$ and ${ }^{13} \mathrm{C}$ NMR spectra. However, two olefinic proton signals of another aculose in $\mathbf{5}$ had disappeared and four aliphatic proton signals $\left(\mathrm{H}-2^{\prime \prime \prime \prime}\left(\delta_{\mathrm{H}} 1.86\right.\right.$ and $\left.\delta_{\mathrm{H}} 2.29\right)$ and $\left.\mathrm{H}-3^{\prime \prime \prime \prime}\left(\delta_{\mathrm{H}} 2.36-2.38,2 \mathrm{H}\right)\right)$ were observed in ${ }^{1} \mathrm{H}$ NMR spectrum of 4 . The presence of a cinerulose, which was a dihydro derivative of an aculose, was indicated from the combination of COSY and HMBC data. This sugar bonded to $\mathrm{C}-3$ of the aglycon chromophore via a glycosidic bond from HMBC data $\left(\mathrm{H}-1^{\prime \prime \prime \prime}\left(\delta_{\mathrm{H}} 5.40\right)\right.$ to $\left.\mathrm{C}-3\left(\delta_{\mathrm{C}} 82.5\right)\right)$ and thus the structure of $\mathbf{4}$ was determined as shown in Figure 3. The total assignments of ${ }^{1} \mathrm{H}$ and ${ }^{13} \mathrm{C}$ NMR signals were demonstrated in Table 3.

Saprolmycin A (1). The ESI-MS spectrum of 1 showed a pseudomolecular ion peak $[\mathrm{M}-\mathrm{H}]^{-}$at $\mathrm{m} / z \mathbf{z}$, the UV-vis and IR data as shown in Table 1 closely resembled those of $\mathbf{5}$ and $\mathbf{6} .{ }^{15}$ The molecular formula of 1 was elucidated to be $\mathrm{C}_{37} \mathrm{H}_{38} \mathrm{O}_{14}$ from its HR-FAB-MS data (found $m / z \quad 713.2407 \quad[\mathrm{M}+\mathrm{Li}]^{+}$, calcd. $m / z \quad 713.2422$ $\left.[\mathrm{M}+\mathrm{Li}]^{+}\right)$, which indicated the lack of $\mathrm{C}_{6} \mathrm{H}_{10} \mathrm{O}_{2}$ corresponding to a rhodinose residue from 5 . There were no signals of a rhodinose moiety in the ${ }^{1} \mathrm{H}$ and ${ }^{13} \mathrm{C}$ NMR spectra of $\mathbf{1}$ but those of two aculoses were observed. $\mathrm{HMBC}$ correlations from the two aculose anomeric protons to the aglycon carbons $\left(\mathrm{H}-1^{\prime \prime}\left(\delta_{\mathrm{H}} 5.37\right)\right.$ to $\mathrm{C}-4^{\prime}\left(\delta_{\mathrm{C}} 89.4\right)$ and $\mathrm{H}-1^{\prime \prime \prime}\left(\delta_{\mathrm{H}} 5.57\right)$ to $\left.\mathrm{C}-3\left(\delta_{\mathrm{C}} 82.8\right)\right)$ indicated aculoses directly connected on the aglycon moiety at C-3 and C-4' via a glycosidic bond. Thus, the structure of $\mathbf{1}$ was determined as shown in Figure 3 and the assignments of ${ }^{1} \mathrm{H}$ and ${ }^{13} \mathrm{C}$ NMR signals were listed in Table 3. The coupling constants of anomeric signals, $\mathrm{H}-1^{\prime \prime} \quad(J=3.4$ $\mathrm{Hz})$, and $\mathrm{H}-1^{\prime \prime \prime}(J=3.4 \mathrm{~Hz})$, indicated that the aculoses in 1 were connected by $\beta$-linkage.

Saprolmycin C (3). The ESI-MS spectrum of 3 showed a pseudomolecular ion peak $[\mathrm{M}-\mathrm{H}]^{-}$at $m / z 705$, the UV-vis and IR data as shown in Table 1 closely resembled those of $\mathbf{5}$ and $\mathbf{6} .{ }^{15}$ The molecular 


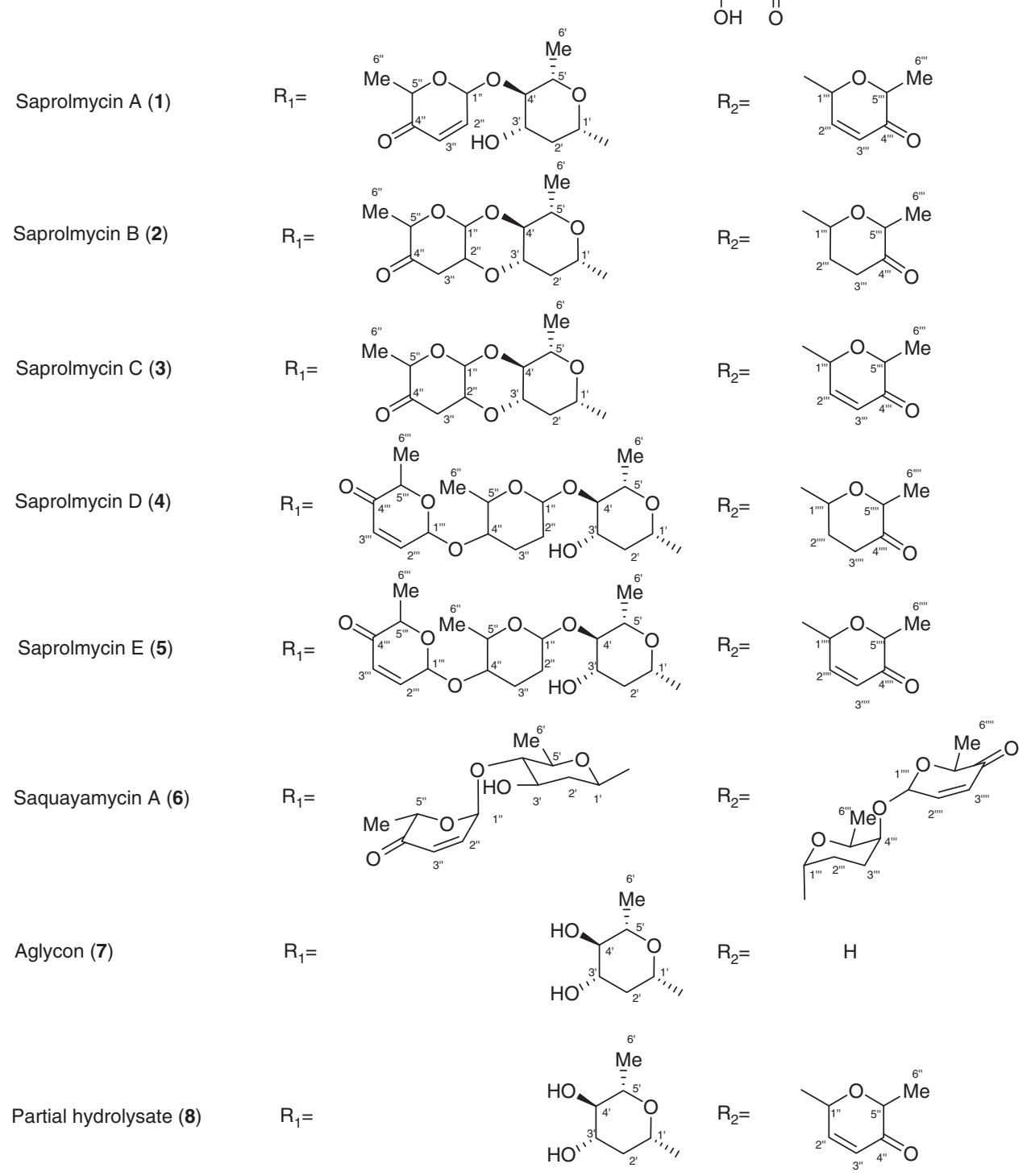

Figure 3 Structures of saprolmycin A (1)-E (5), saquayamycin A (6), aglycon (7) and partial hydrolysate (8).



Figure 4 Summarized COSY and HMBC correlations of partial hydrolysate (8). formula of 3 was elucidated to be $\mathrm{C}_{37} \mathrm{H}_{38} \mathrm{O}_{14}$ from its HR-FAB-MS data (found $\mathrm{m} / \mathrm{z} 713.2407[\mathrm{M}+\mathrm{Li}]^{+}$, calcd. $\mathrm{m} / \mathrm{z} \quad 713.2422$ $\left.[\mathrm{M}+\mathrm{Li}]^{+}\right)$, which was the same molecular formula of $\mathbf{1}$. Comparing the NMR spectra of $\mathbf{1}$ and 3, we found an aculose which bonded to $\mathrm{C}-3$ of the aglycon chromophore via a glycosidic bond from $\mathrm{HMBC}$ data $\left(\mathrm{H}-1^{\prime \prime \prime \prime}\left(\delta_{\mathrm{H}} 5.57\right)\right.$ to $\left.\mathrm{C}-3\left(\delta_{\mathrm{C}} 43.2\right)\right)$ but did not find another aculose moiety. The olefinic proton of second aculose signals in $\mathbf{1}$ disappeared in ${ }^{1} \mathrm{H}$ NMR spectrum of 3 but three aliphatic protons, an oxygenated methine $\left(\mathrm{H}-2^{\prime \prime}\left(\delta_{\mathrm{H}} 4.33\right)\right)$ and a methylene $\left(\mathrm{H}-3^{\prime \prime}\left(\delta_{\mathrm{H}} 2.62-2.66,2 \mathrm{H}\right)\right)$ were observed in 3. COSY and $\mathrm{HMBC}$ data revealed the presence of a 2-oxygenated cinerulose moiety and furthermore $\mathrm{HMBC}$ correlation data $\left(\mathrm{H}-1^{\prime \prime}\left(\delta_{\mathrm{H}} 5.17\right)\right.$ to C-4 ${ }^{\prime}\left(\delta_{\mathrm{C}} 75.1\right) ; \mathrm{H}-3^{\prime}\left(\delta_{\mathrm{H}} 3.81\right)$ to $\left.\mathrm{C}-2^{\prime \prime}\left(\delta_{\mathrm{C}} 71.8\right)\right)$ indicated the formation of a dioxane ring between the aglycon pyran and the cinerulose moieties. Thus, the structure of $\mathbf{3}$ was determined as shown 
Table 3 Assignments of ${ }^{1} \mathrm{H}$ and ${ }^{13} \mathrm{C}$ NMR signals of saprolmycin A (1)-D (4)

\begin{tabular}{|c|c|c|c|c|c|c|c|c|}
\hline \multirow[b]{2}{*}{ Position } & \multicolumn{2}{|r|}{$1^{a}$} & \multicolumn{2}{|r|}{$2^{a}$} & \multicolumn{2}{|r|}{$3^{a}$} & \multicolumn{2}{|r|}{$4^{a}$} \\
\hline & $\delta_{C}$ & $\delta_{H}$ (mult. J in $\mathrm{Hz}$ ) & $\delta_{C}$ & $\delta_{H}$ (mult. J in $\mathrm{Hz}$ ) & $\delta_{C}$ & $\delta_{H}$ (mult. J in $\mathrm{Hz}$ ) & $\delta_{C}$ & $\delta_{H}$ (mult. J in $\mathrm{Hz}$ ) \\
\hline 1 & 204.2 & & 204.5 & & 208.4 & & 204.5 & \\
\hline 2 & 50.2 & $\begin{array}{l}2.55(\mathrm{~m}) \\
3.23(\mathrm{~m})\end{array}$ & 50.5 & $\begin{array}{c}2.51(\mathrm{~d}, 13.1) \\
3.28(\mathrm{dd}, 3.4,13.1)\end{array}$ & 50.8 & $\begin{array}{c}2.54(\mathrm{~d}, 13.8) \\
3.21(\mathrm{dd}, 3.4,13.8)\end{array}$ & 50.5 & $\begin{array}{c}2.51(\mathrm{~d}, 13.1) \\
3.20(\mathrm{dd}, 3.0,13.1)\end{array}$ \\
\hline 3 & 82.8 & & 82.5 & & 83.3 & & 82.5 & \\
\hline 4 & 42.7 & $\begin{array}{c}1.81(\mathrm{~d}, 15.8) \\
2.45(\mathrm{dd}, 2.6,15.8)\end{array}$ & 44.1 & $\begin{array}{c}1.79(\mathrm{~d}, 15.1) \\
2.35(\mathrm{dd}, 3.4,15.4)\end{array}$ & 43.2 & $\begin{array}{c}1.80(\mathrm{~d}, 15.8) \\
2.45(\mathrm{dd}, 2.8,15.8)\end{array}$ & 44.1 & $\begin{array}{c}1.79(\mathrm{~d}, 15.2) \\
2.35(\mathrm{dd}, 3.0,15.2)\end{array}$ \\
\hline $4 a$ & 79.4 & & 79.9 & & 79.9 & & 79.8 & \\
\hline $4 \mathrm{a}-\mathrm{OH}$ & & 3.62 (brs) & & 3.96 (brs) & & 3.56 (brs) & & 3.95 (brs) \\
\hline 5 & 145.3 & $6.40(d, 9.6)$ & 145.3 & $6.42(d, 9.6)$ & 146.0 & $6.40(d, 9.6)$ & 145.3 & $6.41(d, 9.6)$ \\
\hline 6 & 117.4 & $6.90(\mathrm{~d}, 9.6)$ & 117.4 & $6.89(\mathrm{~d}, 9.6)$ & 117.9 & $6.89(d, 9.6)$ & 117.4 & $6.90(\mathrm{~d}, 9.6)$ \\
\hline $6 a$ & 138.5 & & 139.3 & & 139.3 & & 138.1 & \\
\hline 7 & 188.1 & & 188.2 & & 188.8 & & 188.2 & \\
\hline $7 a$ & 114.0 & & 114.6 & & 114.6 & & 113.9 & \\
\hline 8 & 158.1 & & 158.5 & & 158.5 & & 158.1 & \\
\hline $8-\mathrm{OH}$ & & 12.27 (brs) & & 12.28 (brs) & & 12.20 (brs) & & 12.30 (brs) \\
\hline 9 & 138.4 & & 138.5 & & 138.5 & & 138.0 & \\
\hline 10 & 133.7 & $7.88(\mathrm{~d}, 7.6)$ & 133.7 & $7.88(d, 7.6)$ & 134.3 & $7.88(d, 7.6)$ & 133.7 & $7.87(\mathrm{~d}, 7.6)$ \\
\hline 11 & 119.8 & $7.61(\mathrm{~d}, 7.6)$ & 119.8 & $7.61(\mathrm{~d}, 7.6)$ & 120.4 & $7.60(\mathrm{~d}, 7.6)$ & 119.1 & $7.60(\mathrm{~d}, 7.6)$ \\
\hline $11 a$ & 130.5 & & 130.6 & & 131.1 & & 130.4 & \\
\hline 12 & 182.2 & & 182.3 & & 182.8 & & 182.2 & \\
\hline $12 \mathrm{a}$ & 138.8 & & 139.1 & & 139.1 & & 138.2 & \\
\hline $12 b$ & 77.0 & & 77.4 & & 77.1 & & 76.7 & \\
\hline $12 \mathrm{~b}-\mathrm{OH}$ & & 4.67 (brs) & & 4.58 (brs) & & 4.55 (brs) & & 4.58 (brs) \\
\hline 13 & 26.5 & $1.47(\mathrm{~s})$ & 25.8 & $1.45(\mathrm{~s})$ & 27.1 & $1.46(\mathrm{~s})$ & 25.8 & $1.44(\mathrm{~s})$ \\
\hline $1^{\prime}$ & 71.5 & $4.87(\mathrm{dd}, 1.4,11.0)$ & 71.2 & $4.95(\mathrm{dd}, 1.4,11.3)$ & 72.1 & $4.94(d d, 2.1,11.0)$ & 70.5 & $4.86(\mathrm{dd}, 1.4,11.3)$ \\
\hline $2^{\prime}$ & 38.9 & $\begin{array}{l}1.39(\mathrm{~m}) \\
2.55(\mathrm{~m})\end{array}$ & 36.7 & $\begin{array}{c}1.40(\mathrm{~m}) \\
2.43(\mathrm{ddd}, 2.1,4.8,13.1)\end{array}$ & 37.3 & $\begin{array}{l}1.38(\mathrm{~m}) \\
2.45(\mathrm{~m})\end{array}$ & 38.2 & $\begin{array}{l}1.36(\mathrm{~m}) \\
2.50(\mathrm{~m})\end{array}$ \\
\hline $3^{\prime}$ & 71.7 & $3.90(\mathrm{~m})$ & 77.1 & $3.80(\mathrm{~m})$ & 69.9 & $3.81(\mathrm{~m})$ & 70.8 & $3.79(\mathrm{~m})$ \\
\hline $3^{\prime}-\mathrm{OH}$ & & 4.28 (brs) & & & & & & 4.97 (brs) \\
\hline $4^{\prime}$ & 89.4 & $3.20(\mathrm{~m})$ & 74.5 & $3.48(t, 4.1)$ & 75.1 & $3.47(\mathrm{~m})$ & 88.4 & $3.04(t, 8.4)$ \\
\hline $5^{\prime}$ & 74.7 & $3.56(\mathrm{~m})$ & 74.6 & $3.56(\mathrm{~m})$ & 75.2 & $3.55(\mathrm{~m})$ & 73.9 & $3.54(\mathrm{~m})$ \\
\hline $6^{\prime}$ & 18.4 & $1.39(\mathrm{~d}, 6.2)$ & 17.5 & $1.38(\mathrm{~d}, 6.8)$ & 18.1 & $1.38(\mathrm{~d}, 6.2)$ & 18.5 & $1.34(\mathrm{~d}, 6.0)$ \\
\hline $1^{\prime \prime}$ & 95.2 & $5.37(d, 3.4)$ & 91.4 & $5.17(\mathrm{~d}, 3.4)$ & 92.0 & $5.17(\mathrm{~d}, 2.8)$ & 98.9 & 4.97 (brs) \\
\hline $2^{\prime \prime}$ & 142.2 & $6.84(\mathrm{dd}, 3.4,10.3)$ & 71.0 & $4.33(\mathrm{~m})$ & 71.8 & $4.32(\mathrm{~m})$ & 23.8 & $\begin{array}{l}1.67(\mathrm{~m}) \\
2.09(\mathrm{~m})\end{array}$ \\
\hline $3^{\prime \prime}$ & 127.4 & $6.14(d, 10.4)$ & 40.0 & $2.62-2.66(\mathrm{~m}), 2 \mathrm{H}$ & 40.6 & $2.62-2.64(\mathrm{~m}), 2 \mathrm{H}$ & 24.6 & $\begin{array}{l}1.96(\mathrm{~m}) \\
2.08(\mathrm{~m})\end{array}$ \\
\hline $4^{\prime \prime}$ & 195.3 & & 208.0 & & 208.4 & & 75.6 & 3.70 (brs) \\
\hline $5^{\prime \prime}$ & 72.1 & $4.75(q, 6.2)$ & 77.8 & $4.71(q, 6.8)$ & 78.4 & $4.70(q, 7.6)$ & 67.3 & $4.22(\mathrm{~m})$ \\
\hline $6^{\prime \prime}$ & 15.2 & $1.44(\mathrm{~d}, 6.2)$ & 16.9 & $1.39(\mathrm{~d}, 6.2)$ & 16.8 & $1.36(\mathrm{~d}, 7.6)$ & 16.5 & $1.26(\mathrm{~d}, 6.8)$ \\
\hline $1^{\prime \prime \prime}$ & 88.7 & $5.57(d, 3.4)$ & 92.8 & $5.40(t, 6.2)$ & 89.3 & $5.57(d, 3.4)$ & 95.8 & $5.25(\mathrm{~d}, 3.6)$ \\
\hline $2^{\prime \prime \prime}$ & 142.8 & $6.67(\mathrm{dd}, 3.4,10.3)$ & 28.3 & $\begin{array}{c}2.16(\mathrm{~d}, 3.4) \\
2.30(\mathrm{~m})\end{array}$ & 143.4 & $6.67(\mathrm{dd}, 3.4,10.3)$ & 142.8 & $6.87(\mathrm{dd}, 3.6,10.1)$ \\
\hline $3^{\prime \prime \prime}$ & 127.8 & $6.06(d, 9.6)$ & 33.4 & $2.38-2.40(\mathrm{~m}), 2 \mathrm{H}$ & 128.3 & $6.05(d, 10.3)$ & 127.5 & $6.04(d, 10.1)$ \\
\hline $4^{\prime \prime \prime}$ & 196.8 & & 211.0 & & 197.4 & & 197.0 & \\
\hline $5^{\prime \prime \prime}$ & 70.7 & $4.72(q, 6.8)$ & 71.5 & $4.51(q, 6.9)$ & 71.3 & $4.74(q, 7.6)$ & 70.2 & $4.55(q, 6.7)$ \\
\hline $6^{\prime \prime \prime}$ & 15.1 & $1.43(\mathrm{~d}, 6.8)$ & 14.8 & $1.37(\mathrm{~d}, 6.9)$ & 15.7 & $1.42(\mathrm{~d}, 6.9)$ & 14.6 & $1.38(\mathrm{~d}, 6.7)$ \\
\hline $1^{\prime \prime \prime \prime}$ & & & & & & & 92.8 & $5.40(t, 6.3)$ \\
\hline $2^{\prime \prime \prime \prime}$ & & & & & & & 28.3 & $\begin{array}{l}1.86(\mathrm{~m}) \\
2.29(\mathrm{~m})\end{array}$ \\
\hline $3^{\prime \prime \prime \prime}$ & & & & & & & 33.4 & $2.36-2.38(\mathrm{~m}), 2 \mathrm{H}$ \\
\hline $4^{\prime \prime \prime \prime}$ & & & & & & & 210.9 & \\
\hline $5^{\prime \prime \prime \prime}$ & & & & & & & 72.0 & $4.51(q, 6.6)$ \\
\hline $6^{\prime \prime \prime \prime}$ & & & & & & & 14.8 & $1.39(\mathrm{~d}, 6.6)$ \\
\hline
\end{tabular}

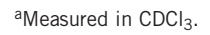


Table 4 Biological activities of saprolmycin A (1)-E (5)

\begin{tabular}{|c|c|c|c|c|c|}
\hline \multirow[b]{2}{*}{ Test organisms } & \multicolumn{5}{|c|}{$M I C\left(\mu g m I^{-1}\right)$} \\
\hline & 1 & 2 & 3 & 4 & 5 \\
\hline Saprolegnia parasitica & 0.0039 & 8 & 1 & 1 & 0.0078 \\
\hline Staphylococcus aureus & 62.5 & 250 & 125 & 62.5 & 15.6 \\
\hline Bacillus subtilis & 125 & 250 & 250 & 62.5 & 7.8 \\
\hline Escherichia coli & $>1000$ & $>1000$ & $>1000$ & $>1000$ & $>1000$ \\
\hline Pseudomonas putida & 500 & $>1000$ & $>1000$ & $>1000$ & $>1000$ \\
\hline Synechocystis sp. & $>100$ & $>100$ & 50 & $>100$ & $>100$ \\
\hline Chlorella kessleri & $>100$ & $>100$ & $>100$ & $>100$ & $>100$ \\
\hline Saccharomyces cerevisiae & $>1000$ & $>1000$ & $>1000$ & $>1000$ & $>1000$ \\
\hline Phoma sp. & $>1000$ & $>1000$ & $>1000$ & $>1000$ & $>1000$ \\
\hline Daphnia pulex & ND & ND & ND & ND & $4.5^{\mathrm{a}}$ \\
\hline
\end{tabular}

Abbreviation: ND, not determined.

aThe value for $D$. pulex was determined as $L D_{50}$.

in Figure 3 and the assignments of ${ }^{1} \mathrm{H}$ and ${ }^{13} \mathrm{C}$ NMR signals of 3 were demonstrated in Table 3.

Saprolmycin B (2). The ESI-MS spectrum of 2 showed a pseudomolecular ion peak $[\mathrm{M}-\mathrm{H}]^{-}$at $m / z 707$, the UV and IR data as shown in Table 1 closely resembled those of $\mathbf{5}$ and $\mathbf{6}^{15}$ The molecular formula of 2 was elucidated to be $\mathrm{C}_{37} \mathrm{H}_{40} \mathrm{O}_{14}$ from its HR-FAB-MS data (found $m / z \quad 715.2603[\mathrm{M}+\mathrm{Li}]^{+}$, calcd. $\mathrm{m} / \mathrm{z} \quad 715.2578$ $\left.[\mathrm{M}+\mathrm{Li}]^{+}\right)$, indicating that 2 was a dihydro derivative of 3 . Comparing the ${ }^{1} \mathrm{H}$ NMR spectra of 2 and 3, we noted that the two olefinic proton signals of an aculose in 3 were not present in 2; however, we did identify four aliphatic protons in 2, namely $\mathrm{H}-2^{\prime \prime \prime}$ $\left(\delta_{\mathrm{H}} 2.16\right.$ and $\left.\delta_{\mathrm{H}} 2.30\right)$ and $\mathrm{H}-3^{\prime \prime \prime}\left(\delta_{\mathrm{H}} 2.38-2.40,2 \mathrm{H}\right)$, indicating the presence of a cinerulose. HMBC connections between the 2-oxygenated cinerulose and the aglycon pyran moieties were observed likewise in 3 indicated the formation of a dioxane ring. Therefore, we considered a cinerulose bonded to C-3 of the aglycon chromophore via a glycosidic bond and it was confirmed by the HMBC correration $\left(\mathrm{H}-1^{\prime \prime \prime}\left(\delta_{\mathrm{H}} 5.40\right)\right.$ to $\left.\mathrm{C}-3\left(\delta_{\mathrm{C}} 82.5\right)\right)$. The structure of 2 was determined as shown in Figure 3 and the total assignments of ${ }^{1} \mathrm{H}$ and ${ }^{13} \mathrm{C}$ NMR signals of 2 were demonstrated in Table 3.

\section{Biological activity}

The five compounds discussed herein are new members of the angucycline antibiotic family, which comprises $>100$ microbial metabolites. ${ }^{18}$ Angucycline compounds are reported to be bioactive substances and include anti-gram-positive bacterial, antitumor and enzyme inhibiting agents. ${ }^{18}$ The biological activities of $\mathbf{1 - 5}$ were measured against $S$. parasitica, fungi, gram-positive and -negative bacteria, green and blue-green algae, and zooplankton. As demonstrated in Table 4, all five compounds showed weak antimicrobial activities against gram-positive bacteria $\left(8-250 \mu \mathrm{g} \mathrm{ml}^{-1}\right)$ but were almost inactive against gram-negative bacteria and fungi $\left(>1000\right.$ and $500 \mu \mathrm{g} \mathrm{ml}^{-1}$ ). These activity profiles are similar to those of known angucycline antibiotics. ${ }^{19-21} 2,3$ and 4 inhibited the growth of $S$. parasitica at a concentration of $1-8 \mu \mathrm{g} \mathrm{ml}^{-1}$. Remarkably, 1 and $\mathbf{5}$, which possess aculoses in their side chains, showed much higher activities against $S$. parasitica at much lower nanogram concentrations $\left(3.9-7.8 \mathrm{ng} \mathrm{ml}^{-1}\right)$. Their activities against green and blue-green algae and zooplankton were $10^{4}$ to $10^{3}$-fold less than those against $S$. parasitica. Overall, these results clearly indicated that $\mathbf{1}$ and $\mathbf{5}$ exhibited high selective activities against $S$. parasitica and low toxicities to environmental planktons, microalgae and zooplankton. Therefore, these compounds may be considered as potent and environmentally safe anti-saprolegniasis candidates for use in the aquaculture industry.

\section{ACKNOWLEDGEMENTS}

Saprolegnia parasitica strain NJM 8602 was kindly provided by Dr Hatai, Nippon Veterinary and Life Science University.

1 Hussein, M. M. A. \& Hatai, K. Pathogenicity of Saprolegnia species associated with outbreaks of salmonid saprolegniosis in Japan. Fish. Sci. 68, 1067-1072 (2002).

2 Patterson, D. J. \& Sogin, M. L. The Origin and Evolution of Prokaryotic and Eukaryotic Cells: Eukaryote Origins and Protistan Diversity pp 13-46 (World Scientific, Singapore, 1992).

3 Alalibo, T. T. et al. Expressed sequence tags from the oomycete fish pathogen Saprolegnia parasitica reveal putative virulence factors. BMC Microbiol. 5, 1-13 (2005).

4 Phillips, A. J., Anderson, V. L., Robertson, E. J., Secombes, C. J. \& West, P. V. New insights into animal pathogenic oomycetes. Trends Microbiol. 16, 13-19 (2008).

5 West, P. V. Saprolegnia parasitica, an oomycete pathogen with a fishy appetite: new challenges for an old problem. Mycologist 20, 99-104 (2006).

6 Willoughby, L. G. \& Roberts, R. J. Towards strategic use of fungicides against Saprolegnia parasitica in salmonid fish hatcheries. J. Fish Dis. 15, 1-13 (1992).

7 Panandiker, A., Fernandes, C. \& Rao, K. V. The cytotoxic properties of malachite green are associated with the increased demethylase, aryl hydrocarbon hydroxylase and lipid peroxidation in primary cultures of Syrian hamster embryo cells. Cancer Lett. 67, 92-101 (1992).

8 Srivastava, S., Sinha, R. \& Roy, D. Toxicology effects of malachite green. Aquat. Toxicol. 66, 319-329 (2004).

9 Nelson, N. C. A Review of the Literature on the Use of Malachite Green in Fisheries. US National Technical Information Service Document No. PB 235-450. pp 79-88 (Washington, DC, 1974).

10 Meyer, F. P. \& Jorgenson, T. A. Teratological and other effects of malachite green on the development of rainbow trout and rabbits. Trans. Amer. Fish. Soc. 112, 818-824 (1983).

11 Kasuga, Y. Hishida, M., Tanahashi, N. \& Arai, M. Studies on disappearance of malachite green in cultured rainbow trout. Shokuhin-Eisei-Shi 33, 539-542 (1992).

12 Meinertz, J. R., Stehly, G. R., Gingerich, W. H. \& Allen, J. L. Residues of $\left[{ }^{14} \mathrm{C}\right]$ malachite green in eggs and fry of rainbow trout, Oncorhynchus mykiss (Walbaum), after treatment of eggs. J. Fish. Dis. 18, 239-247 (1995).

13 Birkbeck, T. H., Reid, H. I., Darde, B. \& Grant, A. N. Activity of bronopol (Pyceze ${ }^{\circledR}$ ) against bacteria cultured from eggs of halibut, Hippoglossus hippoglossus and cod, Gadus morhua. Aquaculture 254, 125-128 (2006).

14 Ohta, K., Mizuta, E., Okazaki, H. \& Kishi, T. The absolute configuration of P-1894B, a potent prolyl hydroxylase inhibitor. Chem. Pharm. Bull. 32, 4350-4359 (1984).

15 Uchida, T. et al. Saquayamycins, new aquayamycin-group antibiotics. J. Antibiot. 38 1171-1181 (1985).

16 Heath, I. B. \& Greenwood, A. D. Wall formation in the saprolegniales. II. Formation of cysts by the zoospores of Saprolegnia and Dictyuchus. Arch. Mikrobiol. 75, 67-79 (1970). 
17 Henkel, T., Rohr, J., Beale, J. M. \& Schwenen, L. Landomycins, new angucycline antibiotics from Streptomyces sp. J. Antibiot. 43, 492-503 (1990).

18 Rohr, J. \& Thiericke, R. Angucycline group antibiotics. Nat. Prod. Rep. 9, 103-137 (1992).

19 Kawashima, A. et al. PI-083, a new platelet aggregation inhibitor. J. Antibiot. 41, 1913-1914 (1988).
20 Hayakawa, Y., Iwakiri, T., Imamura, K., Seto, H. \& Otake, N. Studies on the isotetracenone antibiotics. II. Kerriamycins A, B and C, new antitumor antibiotics. J. Antibiot. 38, 960-963 (1985).

21 Hannelore, D., Hans, Z., Jurgen, R. \& Axel, Z. Metabolic products of microorganism. 234 Urdamycins, new angucycline antibiotics from Streptomyces fradiae. J. Antibiot. 39, 1657-1669 (1986). 